\title{
PLANT SPACING AND ITS EFFECT ON YIELD, FIBRE QUALITY AND PHYSIOLOGICAL PARAMETERS IN COTTON
}

\author{
Rojda ALTUNDAG ${ }^{1}$, Emine KARADEMIR ${ }^{2, *}$ \\ *E-mail: eminekarademirl@siirt.edu.tr
}

Received: Aug. 23, 2021. Revised: Nov. 19, 2021. Accepted: Nov. 22, 2021. Published online: Dec. 7, 2021

\begin{abstract}
The purpose of this study was to see how changing plant spacings affected cotton yield, yield components, fibre quality traits, and physiological parameters. In this study, six plant spacings (no thinning, 5, 10, 15, 20, and $25 \mathrm{~cm}$ ) were investigated. Plant density caused significant differences in the number of first fruiting branches, number of bolls, ginning percentage, seed cotton yield, fibre yield, and normalised difference vegetative index (NDVI). Plant height, the number of sympodial branches, number of monopodial branches, boll weight, seed cotton weight/boll, number of 100-seed weight, seeds/boll, canopy temperature, chlorophyll content, leaf area, and fibre quality properties (micronaire, length, strength, elongation, uniformity, short fibre index, reflectance, yellowness, and spinning consistency index [SCI] were non-significant. The highest values of seed cotton yield, fibre yield, ginning percentage, number of first fruiting branches, and NDVI were obtained in the no thinning and $5 \mathrm{~cm}$ plant spacing
\end{abstract}

\footnotetext{
1 Private Sector, Bursa, Turkey

2 Siirt University, Siirt, Turkey
}

applications, while the highest boll number was obtained at 20 and $25 \mathrm{~cm}$ plant spacings. In this study, physiological parameters, such as canopy temperature, leaf area, chlorophyll content, and fibre technological traits, were not affected by plant spacing. The highest seed cotton yield, fibre yield, ginning percentage and NDVI were obtained from no thinning and $5 \mathrm{~cm}$ intra-row spacing, indicating their impact on examined characteristics. Therefore, a yield estimation can be made in the flowering period with the NDVI in different plant densities in cotton.

Keywords: cotton; plant spacing; yield; physiology; fibre quality.

\section{INTRODUCTION}

Although the cotton plant is mainly grown for its fibre, it is among the most important products in the food industry, with $17-24 \%$ oil content in its seeds. It is one of the most essential raw ingredients used in the 
feed manufacturing process, with a protein content of $35-45 \%$ in its meal after the oil is removed (Kaplan et al., 2017).

In general, cotton is a strategic industrial plant with serious economic importance and constitutes an important raw material for many sectors, such as textiles, oil, food, and animal feedstock (Tumer, 2010). As a result of the ever-increasing population change, the increasing interest in natural fibre, and the increase in living standards, the demand for cotton plants is rapidly increasing.

To increase the yield per unit area, the genetic potential of the variety to be cultivated, and the improvement of agricultural processes, such as irrigation, fertilisation, environmental conditions, plant protection, and cultural processes, can be used to affect the amount of the product.

Aside from these considerations, the optimal number of plants per unit area has a significant impact on yield (Khan et al., 2020). Plant density is an important agronomic factor in cotton, as in many plants. Planting in suitable climatic conditions has a positively impact on yield and quality (Liu et al., 2019).

In contrast, it has been stated that plants with genetic structures tolerant to climate changes will have a shorter stature and appearance in conditions that may change, such as temperature and $\mathrm{CO}_{2}$ increase. In these cases, plants will be insufficient in weed competition due to plant growth in the early development period. To prevent or minimise, such negativities, increasing the plant density is recommended (Hall and Zıska, 2000).

In addition, in cotton cultivation areas, which are of great importance in Turkey, the sowing time is between mid-April and mid-May. In some years, due to the negative climate conditions, planting is late, leading to crop losses. To minimise crop loss in late-planted areas, changing the plants density has been demonstrated as a solution (Delaney et al., 1999).

Many investigations have been conducted in order to establish the most suitable plant density for the varieties grown in cotton farming and the regions in which it is grown (Fang et al., 2014; Wang et al., 2016; Zhi et al., 2016; Liu et al., 2019; Ye et al., 2021). In a team study conducted in Alabama (USA), which is in an almost similar cotton belt, Delaney et al. (1999) stated that dense plant growth provides positive results for early plantings, and sparse planting gives positive results in late plantings.

Kerby et al. (1990) stated that the amount of dry matter in the plant during the first squaring, first flowering, peak flowering, and boll opening period increased in direct proportion with the increase in plant density. In addition, the number of bolls per unit area, leaf area index and plant dry matter accumulation increase inversely with the decrease in the distance between rows in the agricultural area (Samani et al., 1999).

As the number of plants increases, more squares, flowers, and bolls can be obtained from the unit area (Kaynak et al., 1994). Thus, there 
is an increase in leaf area index (LAI) and light retention by the plant due to the increase in plant population density; however, the effect on yield is uncertain (Heitholt and Sassenrath-Cole, 2010).

Crop management practices have a significant impact on the photosynthetic capacity of the canopy. Plant population density affects the structural features of the canopy. For example, factors such as leaf area index, canopy opening, and light distribution significantly affect the photosynthetic capacity of the canopy (Yao et al., 2016).

Although changes in plant spacing have important effects on plant physiology, morphology, canopy development, boll and fibre development, some physiological mechanisms are still not fully understood. As plant density increases, the light flux density in the middle and lower parts of the canopy changes drastically due to shading. This has a direct effect on carbohydrate mechanism.

Plant density is important for the height of the plant and the number of bolls per plant, which are important yield components affecting plant growth parameters, yield, and fibre quality criteria. These traits can be increased with an appropriate planting frequency, thus reducing seed usage costs and sustaining economical production (Bednarz et al., 2000; Zhang et al., 2004; Awan et al., 2011).

Plant density is an important factor in cotton, as in many plants. To achieve high productivity, the optimum number of plants per unit area should be provided.
The purpose of this study was to determine the effects of different plant densities or plant spacings on yield, yield components, fibre quality, and physiological parameters in cotton.

\section{MATERIALS AND METHODS}

This research was carried out in the experimental area of the Faculty of Agriculture of Siirt University in 2017, according to a four-replication randomised block design. 'BA-119' an Upland variety was used as material, as it is preferred due to its adaptability and high yield.

The area where the experiment was carried out was processed deeply with a plough in the fall and outcovered with a cultivator in the spring, and it was made suitable for planting by using the cultivator three times. Soil samples were collected from the trial area for further analyses. The results obtained are listed in Table 1.

As shown in Table 1, the soil had a calcareous structure, with little organic matter; the $\mathrm{pH}$ was slightly alkaline, and the soil texture was clayey. The electrical conductivity was unsalted. The amount of nitrogen, zinc, manganese, and phosphorus in the soil was low, while the amount of copper and iron was sufficient, and the amount of potassium was high. A total of $140 \mathrm{~kg} \cdot \mathrm{ha}^{-1} \mathrm{~N}$ and $80 \mathrm{~kg} \cdot \mathrm{ha}^{-1} \mathrm{P}_{2} \mathrm{O}_{5}$ were incorporated into the planting area. During planting, $80 \mathrm{~kg} \cdot \mathrm{ha}^{-1} \mathrm{~N}$ and $80 \mathrm{~kg} \cdot \mathrm{ha}^{-1}$ $\mathrm{P}_{2} \mathrm{O}_{5}$ 20-20-0 fertiliser were applied to the band with a seeder and the remaining $60 \mathrm{~kg} \cdot \mathrm{ha}^{-1} \mathrm{~N}$ was in the form of $33 \%$ ammonium nitrate during the squaring period/before the first irrigation was applied. 
Table 1 - Soil characteristics of the experimental area

\begin{tabular}{ccc}
\hline Texture & Clay & \\
\hline $\mathrm{pH}$ & 7.98 & Slightly alkaline \\
\hline $\mathrm{EC}(\mathrm{mS} / \mathrm{cm})$ & 0.363 & Unsalted \\
\hline Clay $\left(\% \mathrm{CaCO}_{3}\right)$ & 13.02 & Clayey \\
\hline Organic matter $(\%)$ & 1.31 & Low \\
\hline $\mathrm{N}(\%)$ & 0.082 & Low \\
\hline $\mathrm{P}(\mathrm{ppm})$ & 7.47 & Low \\
\hline $\mathrm{K}(\mathrm{me} / 100 \mathrm{~g})$ & 0.98 & High \\
\hline $\mathrm{Fe}(\mathrm{ppm})$ & 5.70 & Sufficient \\
\hline $\mathrm{Cu}(\mathrm{ppm})$ & 2.63 & Sufficient \\
\hline $\mathrm{Zn}(\mathrm{ppm})$ & 0.23 & Low \\
\hline $\mathrm{Mn}(\mathrm{ppm})$ & 6.04 & Low
\end{tabular}

In the experiment, sowing occurred on May 4, 2017, with a seeder. At sowing, each plot was formed from 4 rows of $12 \mathrm{~m}$ in length. During sowing, the distance between rows was $0.70 \mathrm{~m}$, and the distance between inter-rows was created by thinning with the help of a ruler at 5 , $10,15,20$, and $25 \mathrm{~cm}$ and no thinning. The applications were as follows:

1) No thinning $\left(572,420\right.$ plants $\left.\mathrm{ha}^{-1}\right)$

2) $5 \mathrm{~cm}\left(285,710\right.$ plants $\left.\mathrm{ha}^{-1}\right)$

3) $10 \mathrm{~cm}\left(142,850\right.$ plants $\left.\mathrm{ha}^{-1}\right)$

4) $15 \mathrm{~cm}\left(95,230\right.$ plants $\left.\mathrm{ha}^{-1}\right)$

5) $20 \mathrm{~cm}\left(71,420\right.$ plants ha- $\left.{ }^{-1}\right)$

6) $25 \mathrm{~cm}\left(57,140\right.$ plants ha $\left.{ }^{-1}\right)$.

All maintenance operations in the trial were carried out when necessary. When the height of the plants has reached $10-15 \mathrm{~cm}$, the in-row plant density was created by thinning. During the experiment, hoeing was performed three times by hand and twice with a machine. Pest control occurred at regular intervals, and no pesticide was applied because it was not needed. The experiment was irrigated using the drip irrigation method. Irrigation was determined according to the plant's water demand. Irrigation was started before the flowering period and completed at the $10 \%$ boll opening period. Harvesting operations were done manually and completed twice. The first harvest was carried out during the $60 \%$ boll opening period, and the remaining cotton was collected at the second harvest.

Two rows in the centre of the plots were harvested during harvest.. The first harvest occurred on October 2, and the second harvest occurred on October 25, 2017. The climate data of the year in which the experiment was carried out are given in Table 2, in comparison with the long years. The average temperature 2017 was higher than that in other years, and the minimum and maximum temperature values were lower than in other years. In 2017, the highest precipitation in April was $132.8 \mathrm{~mm}$, which was higher than in long years, and there was no precipitation between June and September.

\section{Examined Properties and Determination Methods}

Agronomic Traits. Plant height, monopodial branch count, fruiting branch count, nodes on first fruiting branches count and boll count were all recorded in ten randomly selected plants from each plot and 50 bolls were collected in the $1^{\text {st }}$ position between the $1^{\text {st }}$ and $5^{\text {th }}$ fruit branches from each plot. The boll weight, boll seed cotton weight, 100 -seed weight, number of 


\section{Rojda ALTUNDAG, Emine KARADEMIR}

seeds per boll, and ginning percentage were determined.

The weight of the boll, the weight of the boll seed cotton, 100-seed weight, the number of seeds per boll, and the ginning percentage were determined.

Seed cotton yield values were obtained by weighing the product obtained from each parcel and the yield of the parcel converted to $\mathrm{kg} \mathrm{ha}^{-1}$. Physiological observations were examined during the flowering period, and information about the physiological observations is given below.

Leaf/Canopy Temperature $\left({ }^{\circ} \mathrm{C}\right)$. Leaf/canopy temperature was determined using a Spectrum Brand 2956 Model Infrared Thermometer (Pask et al., 2012).

Chlorophyll Content (SPAD value). Chlorophyll content was determined with the Minolta SPAD 502 instrument in 10 randomly selected plants during the flowering period. The top five newly opened and fully grown leaves of the plant were used to record measurements (Johnson and Sounders, 2003).

Leaf Area. In one randomly selected plant from each plot, the top 5th newly opened and fully developed leaf was cut off and drawn on A4 paper. Then, the image was scanned, and the leaf area was determined using the AutoCAD program.

Normalised Difference Vegetative Index (NDVI). The NDVI was determined using a Trimble brand GreenSeeker instrument. Values were recorded by holding the sensor 76 to $91 \mathrm{~cm}$ above the plant canopy (Gwathmey et al., 2010; Gwathmey et al., 2011).

Laboratory Analyses. Fibre analyses were determined in the fibre quality laboratory of the GAP International Agricultural Research and Training Center with the help of the HVI 1000 instrument.

Statistical Analyses. The results were evaluated using the JMP 7.0 statistical program, and the $\operatorname{LSD}_{(0.05)}$ test was used to compare the averages.

\section{RESULTS AND DISCUSSION}

Plant Height (cm) varied between 76.16 and $83.16 \mathrm{~cm}$, but there were no statistically significant differences between the applications (Table 3). The lowest plant height was obtained in the no thinning application at $76.16 \mathrm{~cm}$, while the highest value was obtained from the application at a $20 \mathrm{~cm}$ plant density at $83.16 \mathrm{~cm}$. The increase in plant density slightly decreased the plant height, but the differences were not significant.

Similar findings were reported by Wang et al. (2016). These findings differed from those that stated that plant height decreased with the increase in plant density (Kaynak, 1995) and that plant height was highest at a density of $7 \mathrm{~m}^{2}$ (Stephenson et al. 2011). The differences between studies likely occurred because they were conducted in different climatic conditions, and the variety and cultural processes differed.

Number of Monopodial Branches (number plant ${ }^{-1}$ ) varied between 0.89 and 1.91 per plant, but differences between applications were not statistically significant (Table 3). While the lowest value was obtained from $10 \mathrm{~cm}$ plant spacing (0.89), the highest number of monopodial branches was obtained at $20 \mathrm{~cm}$ plant spacing (1.91 plant $\left.^{-1}\right)$.

These results were consistent with those of Incekara and Turan (1997), who stated that the increasing number of plants per unit area did not 
cause any difference in the number of monopodial branches. These findings differed from those that reported an increase in the number of monopodial branches when the plant density decreased (Düven, 1992) and that the number of monopodial branches decreased as the distance between rows decreased (Kaynak, 1995; Azizpour et al., 2005).

Table 2 - Climate data for the year 2017 and long-term periods

\begin{tabular}{ccccccccccc}
\hline \multirow{2}{*}{ Month } & $\begin{array}{c}\text { Average } \\
\text { Temperature } \\
\left({ }^{\circ} \mathbf{C}\right)\end{array}$ & $\begin{array}{c}\text { Min. } \\
\text { Temperature } \\
\left({ }^{\circ} \mathbf{C}\right)\end{array}$ & $\begin{array}{c}\text { Max. } \\
\text { Temperature } \\
\left({ }^{\circ} \mathbf{C}\right)\end{array}$ & \multicolumn{2}{c}{$\begin{array}{c}\text { Rainfall } \\
(\mathbf{m m})\end{array}$} & $\begin{array}{c}\text { Relative } \\
\text { Humidity } \\
(\%)\end{array}$ \\
\cline { 2 - 11 } & $\mathbf{2 0 1 7}$ & $\begin{array}{c}\text { Long } \\
\text { Term }\end{array}$ & $\mathbf{2 0 1 7}$ & $\begin{array}{c}\text { Long } \\
\text { Term }\end{array}$ & $\mathbf{2 0 1 7}$ & $\begin{array}{c}\text { Long } \\
\text { Term }\end{array}$ & $\mathbf{2 0 1 7}$ & $\begin{array}{c}\text { Long } \\
\text { Term }\end{array}$ & $\mathbf{2 0 1 7}$ & $\begin{array}{c}\text { Long } \\
\text { Term }\end{array}$ \\
\hline April & 14.0 & 13.8 & 4.3 & 8.9 & 25.9 & 19.1 & 132.8 & 105.1 & 59.5 & 57.5 \\
May & 19.5 & 19.2 & 10.1 & 9.0 & 32.0 & 36.1 & 74.6 & 66.8 & 51.7 & 50.1 \\
June & 26.9 & 25.9 & 12.8 & 17.8 & 39.8 & 40.2 & 0.0 & 9.3 & 29.5 & 34.1 \\
July & 32.3 & 30.5 & 22.1 & 23.4 & 41.2 & 44.4 & 0.0 & 1.6 & 19.0 & 26.6 \\
August & 32.0 & 30.0 & 21.5 & 27.0 & 42.9 & 46.0 & 0.4 & 0.9 & 19.0 & 25.7 \\
September & 28.4 & 25.0 & 17.2 & 14.7 & 39.5 & 39.9 & 0.0 & 5.2 & 19.1 & 30.9 \\
October & 18.4 & 17.9 & 9.8 & 12.7 & 28,4 & 36.6 & 5.2 & 48.8 & 34.6 & 46.5 \\
\hline
\end{tabular}

General Directorate of Meteorology, Siirt Station, Average of long-term period: 1950-2015

Table 3 - Average values for the investigated agronomic properties and LSD test

\begin{tabular}{|c|c|c|c|c|c|c|c|c|}
\hline $\begin{array}{l}\text { Plant } \\
\text { Spacing }\end{array}$ & PH & NMB & NSB & NNFFB & BN & BW & BSCW & NSPB \\
\hline $\begin{array}{l}\text { No } \\
\text { thinning }\end{array}$ & 76.16 & 1.08 & 8.41 & $7.41 \mathrm{a}$ & $8.74 \mathrm{bc}$ & 5.29 & 3.87 & 29.25 \\
\hline $5 \mathrm{~cm}$ & 77.41 & 1.16 & 7.66 & $7.66 \mathrm{a}$ & $6.74 \mathrm{c}$ & 5.55 & 3.99 & 27.70 \\
\hline $10 \mathrm{~cm}$ & 78.58 & 0.89 & 8.33 & $6.99 a b$ & 8.74 bc & 5.71 & 4.15 & 29.70 \\
\hline $15 \mathrm{~cm}$ & 78.99 & 0.91 & 9.83 & $5.57 \mathrm{c}$ & $10.58 a b$ & 5.44 & 3.94 & 27.65 \\
\hline $20 \mathrm{~cm}$ & 83.16 & 1.91 & 10.49 & $7.08 \mathrm{a}$ & $11.58 \mathrm{a}$ & 5.61 & 4.04 & 28.60 \\
\hline $25 \mathrm{~cm}$ & 80.24 & 1.16 & 10.33 & $5.83 \mathrm{bc}$ & $11.41 \mathrm{a}$ & 5.61 & 4.06 & 27.45 \\
\hline Mean & 79.09 & 1.18 & 9.7 & 6.76 & 6.93 & 5.53 & 4.01 & 28.39 \\
\hline CV (\%) & 5.29 & 45.76 & 14.31 & 11.52 & 14.13 & 5.36 & 5.48 & 8.34 \\
\hline LSD (0.05) & ns & ns & ns & $1.17^{* *}$ & $2.04^{* *}$ & ns & ns & ns \\
\hline
\end{tabular}

${ }^{*},{ }^{* *}$; Significant at $p \leq 0.05$ and $p \leq 0.01$, respectively; PH: Plant height $(\mathrm{cm})$, NMB: Number of monopodial branches (number $\cdot$ plant $^{-1}$ ), NSB: Number of sympodial branches (number plant ${ }^{-1}$ ), NNFFB: Number of nodes in first fruiting branches (number $\cdot$ plant $^{-1}$ ), BN: Boll number (number plant ${ }^{-1}$ ), BW: Boll weight $(\mathrm{g})$, BSCW: Boll seed cotton weight $(\mathrm{g})$, NSPB: Number of seeds per boll (number plant ${ }^{-1}$ )

Number of Fruiting Branches (number plant $^{-1}$ ) varied between 7.66 and 10.49 plant $^{-1}$, but the differences between applications were not statistically significant (Table 3). The lowest value was obtained at a $5 \mathrm{~cm}$ plant spacing, with 7.66 plant $^{-1}$, and the highest number of fruiting branches was obtained from at a $20 \mathrm{~cm}$ plant spacing, with 10.49 plant $^{-1}$. These results were compatible with those that demonstrated that an increasing plant number per unit area did not cause any change in the 


\section{Rojda ALTUNDAG, Emine KARADEMIR}

number of fruiting branches (Incekara and Turan, 1977; Kaynak, 1995).

The number of fruit branches has been reported to increase as plant density decreases (Düven, 1992; Kumar et al., 2017), and the number of fruit branches decreases as the distance between the rows decreases (the plant density increases in a unit area) (Kaynak et al., 1994; Azizpour et al., 2005). However, the research findings differ, likely due to differences in climatic conditions and variety.

Number of Nodes in First Fruiting Branches (number plant ${ }^{-1}$ ) varied between 5.57 and 7.66 plant $^{-1}$, and there were statistical differences between applications at the $1 \%$ significance level. The lowest number of nodes of the first fruiting branches was obtained at a $15 \mathrm{~cm}$ plant density, with 5.57 plant $^{-1}$, and the highest value was obtained at a $5 \mathrm{~cm}$ plant density, with 7.66 plant $^{-1}$.

The $5 \mathrm{~cm}$ plant density and the no thinning application were not significantly different. The number of nodes in the first fruiting branches was influenced by plant density. Similar findings have also been reported by Wang et al. (2016). However, Akbar et al. (2015) found that the number of nodes in first fruiting branches was not affected by a 10,20 , or $30 \mathrm{~cm}$ in-row distance.

Number of Bolls (number • plant $^{-1}$ ) ranged between 6.74 and 11.58 plant $^{-1}$. There were statistical differences between the applications at the $1 \%$ significance level, and the general average of the experiment was 6.93 plant $^{-1}$. The lowest number of bolls was obtained at a $5 \mathrm{~cm}$ plant density $\left(6.74\right.$ plant $\left.^{-1}\right)$. The highest value was obtained at a $20 \mathrm{~cm}$ plant density (11.58 plant $\left.^{-1}\right)$, followed by 25 and $15 \mathrm{~cm}$ planting densities, and these applications were not significantly different. Plant density had a significant influence on the number of bolls and the number of bolls increased as the plant density decreased or the distance between rows increased.

As plant density decreases, the number of bolls increases (Düven, 1992; Stephenson et al. 2011; Silva et al. 2012; Sawan, 2016), and the number of bolls decreases as the distance between the rows decreases (as the plant density increases in a unit area). The findings of Kaynak et al. (1994) supported the results of this study. Different findings were obtained by Bednarz et al. (2000), who stated that a low plant density did not affect the number of bolls.

Boll Weight (g). varied between 5.29 and $5.71 \mathrm{~g}$, but there were no statistically significant differences. The lowest boll weight was obtained in the no thinning treatment $(5.29 \mathrm{~g})$, while the highest boll weight was obtained at a $10 \mathrm{~cm}$ plant density $(5.71 \mathrm{~g})$. Plant density did not have a significant influence on boll weight. Similar findings were also reported by lqbal et al. (2012) and McCarty et al. (2017). It has been reported that as the distance between rows decreases, the boll weight decreases (Kaynak et al. 1994; Zhi et al., 2016; Darawsheh et al., 2019), which differs from the present findings. These differences may be caused by the differences in climatic 
conditions, the variety used, and cultural processes used in the years the research was conducted.

Boll Seed Cotton Weight (g) varied between 3.87 and $4.15 \mathrm{~g}$, but the differences between applications were not statistically significant. The lowest boll seed cotton weight was obtained in the no thinning treatment $(3.87 \mathrm{~g})$, while the highest value was obtained at a $10 \mathrm{~cm}$ plant density (4.15 g).

The findings showed that plant density had no effect on boll seed cotton weight (Incekara and Turan, 1977), which is similar to the results of Akçar and Gençer (1987). Different results were obtained in this study compared with those reporting that the boll seed cotton weight decreases as the distance between rows decreases (Düven, 1992; Kaynak, 1995; Kaynak et al., 2014; Zhi et al., 2016).

Number of Seeds in the Boll (number boll ${ }^{-1}$ ). ranged between 27.45 and 29.70 , but there were no statistically significant differences (Table 3). The lowest value was obtained at a $25 \mathrm{~cm}$ plant density $\left(27.45\right.$ boll $\left.^{-1}\right)$, while the highest value was obtained at a $10 \mathrm{~cm}$ plant density $\left(29.70\right.$ boll $\left.^{-1}\right)$. Similar results were observed in Akbar et al (2015) and Mahil and Lokanadhan (2017), who reported that plant density did not affect the number of seeds in the boll. In contrast, Zhi et al. (2016) reported that the number of seeds in the boll increased as the plant density decreased.

100-Seed Weight (g). The weight of 100 seeds varied between 8.15 and $8.35 \mathrm{~g}$, but the differences between applications were not statistically significant (Table 4). The lowest 100 -seed weight was obtained in the no thinning application, at $8.15 \mathrm{~g}$, and the highest value was obtained at a $25 \mathrm{~cm}$ plant density, at $8.35 \mathrm{~g}$. Previous reports have stated that the effect of plant density on the weight of 100 seeds was not significant (Akçar and Gençer, 1987), that the weight of 100 seeds increases as the distance between the rows decreases (Kaynak et al., 1994), and that the weight of 100 seeds decreases with the increase in plant density (Zhao et al., 2019). These findings differed from those that reported no change in the weight of 100 seeds as the distance between rows decreased (the plant density increased in a unit area (Kaynak, 1995).

Ginning Percentage (\%). As shown in Table 4, there were significant differences between applications at the $1 \%$ significance level in terms of ginning percentage. The average values of the ginning percentage ranged between 40.30 and $43.36 \%$, and the general average of the trial was $42.41 \%$. The lowest ginning percentage value was obtained at a $20 \mathrm{~cm}$ plant density, while the highest value was obtained at a $5 \mathrm{~cm}$ plant density, followed by the no thinning application (43.03\%).

Plant density was found to have a significant effect on ginning percentage. Similar findings were reported by Awan et al. (2011). As the distance between the rows decreases (the plant density increases in the unit area), the ginning percentage decreases (Kaynak et al., 1994). The ginning 


\section{Rojda ALTUNDAG, Emine KARADEMIR}

percentage is not affected by a narrow row planting method (Özdemir, 2007), and the decrease in the plant density does not have a significant effect on the ginning percentage (Akbar et al., 2015; Sawan, 2016).

Table 4 - Average values for the investigated agronomic and physiological properties

\begin{tabular}{|c|c|c|c|c|c|c|c|c|}
\hline $\begin{array}{c}\text { Plant } \\
\text { Spacing }\end{array}$ & $\begin{array}{l}100 \\
\text { SW }\end{array}$ & GP & SCY & FY & LT & CC & NDVI & LA \\
\hline No thinning & 8.15 & 43.0 & 458 & 1972 & 33 & 43. & $b$ & 66.60 \\
\hline $5 \mathrm{~cm}$ & 8.22 & 43.3 & 416 & 1809 & & 41 & & 60.32 \\
\hline $10 \mathrm{~cm}$ & 8.18 & $42.67 \mathrm{ab}$ & 3825 & 1630. & 30 & 43.07 & $a b c$ & 63.34 \\
\hline $15 \mathrm{~cm}$ & 8.22 & 42.1 & 3528 & 1488 & 33 & & & 60.07 \\
\hline $20 \mathrm{~cm}$ & 8.26 & 40.3 & 358 & 145 & 32.32 & 42.45 & c & 58.51 \\
\hline $25 \mathrm{~cm}$ & 8.35 & $42.93 \mathrm{ab}$ & $3438.60 \mathrm{c}$ & $1476.40 \mathrm{c}$ & 31.25 & 42.65 & $0.76 \mathrm{bc}$ & 72.72 \\
\hline Mean & 8.23 & 42.41 & 3855.00 & 1637.90 & 32.02 & 42.51 & 0.77 & 63.60 \\
\hline CV (\%) & 4.49 & 1.61 & 11.31 & 10.77 & 10.43 & 10.45 & 4.15 & 10.82 \\
\hline LSD (0.05) & ns & $1.02^{* *}$ & $657.25^{*}$ & $265.73^{* *}$ & ns & ns & $0.04^{*}$ & ns \\
\hline
\end{tabular}

${ }^{*},{ }^{* *}$, Significant at $p \leq 0.05$ and $p \leq 0.01$, respectively; 100 SW: 100 -seed weight (g), GP: Ginning percentage (\%), SCY: Seed cotton yield $\left(\mathrm{kg} \mathrm{ha}^{-1}\right)$, FY: Fibre yield $\left(\mathrm{kg} \mathrm{ha}^{-1}\right)$, LT: Leaf temperature $\left({ }^{\circ} \mathrm{C}\right), \mathrm{CC}$ : Chlorophyll content (SPAD value), NDVI: Normalised difference vegetative index, LA: Leaf area $\left(\mathrm{cm}^{2}\right)$

Seed Cotton Yield (kg ha $\left.{ }^{-1}\right)$ varied between 3438.60 and $4583.30 \mathrm{~kg} \mathrm{ha}^{-1}$; as seen in Table 4, there were statistical differences between applications at the 5\% significance level, and the general average of the experiment was $3855.00 \mathrm{~kg} \mathrm{ha}^{-1}$. The lowest seed cotton yield was obtained at a $25 \mathrm{~cm}$ plant density $\left(3438.60 \mathrm{~kg} \mathrm{ha}^{-1}\right)$. The highest value was obtained in the no thinning application (4583.30 kg ha $\left.{ }^{-1}\right)$, followed by a $5 \mathrm{~cm}$ plant density $\left(4165.40 \mathrm{~kg} \mathrm{ha}^{-1}\right)$ and these applications were not significantly different. In this study, the seed cotton yield decreased with the decrease in plant population.

The seed cotton yield increased with the increasing number of plants per unit area (Incekara and Turan, 1977; Azizpour et al., 2005; Ali et al., 2009; Chen et al., 2019; Liu et al., 2019). Darawsheh et al. (2009b) confirmed these research findings.
Bednarz et al. (2000) found that the seed cotton yield was not affected by plant density, differing from the results of this study.

Fibre Yield $\left(\mathrm{kg} \mathrm{ha}^{-1}\right)$ varied between 1450.50 and $1972.40 \mathrm{~kg} \mathrm{ha}^{-1}$ and there were statistical differences between applications at the $1 \%$ significance level. The lowest value was obtained at a $20 \mathrm{~cm}$ plant spacing $\left(1450.50 \mathrm{~kg} \mathrm{ha}^{-1}\right)$. The highest value was obtained in the no thinning application $\left(1972.40 \mathrm{~kg} \mathrm{ha}^{-1}\right)$, followed by $5 \mathrm{~cm}$ plant spacing (1809.20 kg ha $\left.{ }^{-1}\right)$. Plant spacing had a significant influence on fibre yield, and the highest fibre yield was obtained in the no thinning application.

Increasing plant density causes an increase in fibre yield (Unay and Inan, 1994; Mert et al., 2005; Zhi et al., 2016; Liu et al., 2019), and narrow row planting has the potential to increase yield (Heitholt, 1995). However, these 
research findings differed from those that reported no differences between row spacings (Jost et al., 1998) and that showed the highest fibre yield at a 7.5 plant $\mathrm{m}^{2}$ spacing in late sowing (Dong et al., 2005).

Leaf/Canopy Temperature $\left({ }^{\circ} \mathrm{C}\right)$ varied between 30.35 and $33.17^{\circ} \mathrm{C}$, but differences between applications were not significant. The lowest value was obtained at a $10 \mathrm{~cm}$ plant spacing, while the highest value was obtained in the no thinning application.

Xie et al. (2016) reported that canopy temperature decreased with increased plant density, which differed from the present findings. This may have been due to differences in climate, temperature, humidity, leaf/canopy temperature measurements and irrigation.

\section{Leaf Chlorophyll Content} (SPAD value) varied between 41.25 and 43.75, but no significant difference was observed between applications. The highest chlorophyll content was obtained in the no thinning application (43.75), and the lowest value was obtained at a $15 \mathrm{~cm}$ plant spacing (41.25). While the findings were in agreement with Janat and Khalout (2011), who reported that the chlorophyll content in the leaf was not influenced by plant density, Xie et al. (2016) obtained different results.

\section{Normalised}

Difference

Vegetative Index (NDVI). NDVI values ranged from 0.74 to 0.81 , and there were differences between applications at the 5\% significance level. The lowest NDVI was obtained at a 15 and $20 \mathrm{~cm}$ plant spacing (0.74).
The highest NDVI was obtained at a $5 \mathrm{~cm}$ plant spacing $(0.81)$, followed by the no thinning application $(0.80)$, and the NDVI values for these applications were not significantly different. The NDVI was affected by plant density, which was confirmed by Ramirez et al. (2017).

Leaf Area $\left(\mathrm{cm}^{2}\right)$ varied between 58.51 and $72.72 \mathrm{~cm}^{2}$, but the differences between applications were not statistically significant. The lowest value was obtained at a $20 \mathrm{~cm}$ plant spacing $\left(58.51 \mathrm{~cm}^{2}\right)$, and the highest value was obtained at a $25 \mathrm{~cm}$ plant spacing $\left(72.72 \mathrm{~cm}^{2}\right)$. Plant density applications did not cause a significant difference in leaf area. Similar findings were also reported by Janat and Khalout (2011). However, these results differed from other studies, which showed that an increase in plant density increased the leaf area (Darawsheh et al., 2009a; Liu et al., 2019).

Fibre Micronaire (mic) ranged from 3.78 to $4.30 \mathrm{mic}$. The differences between applications were not statistically significant (Table 5). The lowest value was obtained in the no thinning application (3.78 mic), while the highest value was obtained at a $25 \mathrm{~cm}$ plant spacing $(4.30 \mathrm{mic})$.

Previous studies have reported that plant density does not have a significant effect on fibre micronaire (Bednarz et al., 2005; Özdemir, 2007; Janat and Khalout, 2011; Stephenson et al., 2011).

Fibre Length (mm) varied between $27.57 \mathrm{~mm}$ and $28.12 \mathrm{~mm}$, and the differences between applications were not statistically significant. The 


\section{Rojda ALTUNDAG, Emine KARADEMIR}

lowest fibre length was obtained from at a $15 \mathrm{~cm}$ plant spacing $(27.57 \mathrm{~mm})$, and the highest value was obtained at a $25 \mathrm{~cm}$ plant spacing $(28.12 \mathrm{~mm})$. It has been reported that plant density does not affect fibre length (Hawkins and Peacock, 1971; Bridge et al., 1972; Baker, 1976; Janat and Khalout, 2011; Stephenson et al., 2011), which agrees with the present results.

Fibre Strength $\left(\mathrm{g} \cdot\right.$ tex $\left.^{-1}\right)$. As shown in Table 5, fibre strength varied between 29.47 and $31.05 \mathrm{~g} \cdot$ tex $^{-1}$, and the differences between applications were not significant. The lowest value was obtained in the no thinning application, with $29.47 \mathrm{~g} \cdot$ tex $^{-1}$, and the highest value was obtained at a $15 \mathrm{~cm}$ plant spacing $\left(31.05 \mathrm{~g} \cdot \mathrm{tex}^{-1}\right)$.

It has been reported that plant density does not affect fibre strength (Bridge et al., 1972; Stephenson et al., 2011), which agrees with the present findings.

Fibre Elongation (\%) values ranged between 6.15 and $6.57 \%$. Although there was no significant difference between the applications, the lowest fibre elongation was obtained at a $10 \mathrm{~cm}$ plant spacing, while the highest fibre elongation was obtained at a $5 \mathrm{~cm}$ plant spacing. These results were supported by previous studies demonstrating that increasing plant density does not have a significant effect on fibre elongation (Bridge et al., 1972; Stephenson et al., 2011).

Fibre Uniformity Ratio (\%) varied between 83.32 and $84.12 \%$, but the differences were not statistically significant. The lowest fibre uniformity ratio was obtained at a $20 \mathrm{~cm}$ plant spacing, while the highest value was obtained at a $25 \mathrm{~cm}$ plant spacing. Similar results were reported by Stephenson et al. (2011) who reported that the fibre uniformity ratio was not affected by the increase in plant density.

Short Fibre Index (\%) varied between 6.90 and $8.30 \%$, but the differences between applications were not statistically significant. The lowest short fibre index was obtained at a $25 \mathrm{~cm}$ plant spacing $(6.90 \%)$, while the highest value was obtained at a $20 \mathrm{~cm}$ plant spacing $(8.30 \%)$. Plant density or plant spacing did not affect the short fibre index. Similar findings were also reported by Darawsheh et al. (2009b), Sawan (2016) and Afzal et al. (2018).

Fibre Reflectance (Rd) Fibre reflectance (Rd) varied between 79.07 and 79.45 , but the differences between applications were not statistically significant. The lowest Rd value was obtained at a $15 \mathrm{~cm}$ plant spacing (79.07), and the highest $\mathrm{Rd}$ value was obtained at a $5 \mathrm{~cm}$ plant spacing (79.45). Fibre reflectance was not affected by plant density. Similar findings were also reported by (Darawsheh et al., 2009b; Sawan 2016; Afzal et al., 2018).

Fibre yellowness varied between 10.22 and 11.10 , but the differences were not significant. The lowest fibre yellowness value was obtained in the no thinning application, while the highest value was obtained at a $20 \mathrm{~cm}$ plant spacing. 
Table 5 - Average values for the investigated fibre quality traits

\begin{tabular}{cccccccccc}
\hline Plant Spacing & Mic & FL & FS & FE & FU & SFI & RD & \%b & SCI \\
\hline No thinning & 3.78 & 27.65 & 29.47 & 6.40 & 83.57 & 7.37 & 79.22 & 10.22 & 140.25 \\
$5 \mathrm{~cm}$ & 3.90 & 27.91 & 30.50 & 6.57 & 83.57 & 7.47 & 79.45 & 10.52 & 143.25 \\
$10 \mathrm{~cm}$ & 4.16 & 27.62 & 30.52 & 6.15 & 83.95 & 7.17 & 79.42 & 10.60 & 141.75 \\
$15 \mathrm{~cm}$ & 4.16 & 27.57 & 31.05 & 6.37 & 83.62 & 8.12 & 79.07 & 10.60 & 141.50 \\
$20 \mathrm{~cm}$ & 4.12 & 27.86 & 29.65 & 6.32 & 83.32 & 8.30 & 79.27 & 11.10 & 137.50 \\
$25 \mathrm{~cm}$ & 4.30 & 28.12 & 30.25 & 6.20 & 84.12 & 6.90 & 79.20 & 10.62 & 141.50 \\
\hline Mean & $\mathbf{4 . 0 7}$ & $\mathbf{2 7 . 7 9}$ & $\mathbf{3 0 . 2 4}$ & $\mathbf{6 . 3 3}$ & $\mathbf{8 3 . 6 9}$ & $\mathbf{7 . 5 5}$ & $\mathbf{7 9 . 2 7}$ & $\mathbf{1 0 . 6 1}$ & $\mathbf{1 4 0 . 9 5}$ \\
\hline CV (\%) & $\mathbf{7 . 1 2}$ & $\mathbf{2 . 5 1}$ & $\mathbf{8 . 5 9}$ & $\mathbf{4 . 6 4}$ & $\mathbf{1 . 3 7}$ & $\mathbf{1 2 . 7 1}$ & $\mathbf{0 . 8 5}$ & $\mathbf{3 . 9 1}$ & $\mathbf{8 . 4 1}$ \\
\hline LSD (0.05) & ns & ns & ns & ns & ns & ns & ns & ns & ns \\
\hline
\end{tabular}

${ }^{*},{ }^{* *}$, Significant at $p \leq 0.05$ and $p \leq 0.01$, respectively; Mic: Fibre micronaire,

FL: Fibre length (mm), FS: Fibre strength $\left(\mathrm{g} \cdot \mathrm{tex}^{-1}\right)$, FE: Fibre elongation $(\%)$,

FU: Fibre uniformity (\%), SFI: Short fibre index (\%), RD: Fibre reflectance, +b: Fibre yellowness, SCI: Spinning consistency index

\section{Spinning Consistency Index} (SCI) varied between 137.50 and 143.25 , but the differences between the applications were not statistically significant. The lowest SCI index was obtained at a $20 \mathrm{~cm}$ plant spacing, while the highest value was obtained at a $5 \mathrm{~cm}$ plant spacing. Similar results were obtained by Mert et al. (2005), Darawsheh et al., (2009b), Janat and Khalout (2011) and Sawan (2016).

\section{CONCLUSIONS}

In this study, different plant spacings (no thinning, 5, 10, 15, 20 and $25 \mathrm{~cm}$ ) were compared. The highest values in terms of number of nodes of first fruiting branches, ginning percentage, seed cotton yield, fibre yield, and NDVI value were observed at a $5 \mathrm{~cm}$ plant spacing and in the no thinning application. The highest number of bolls per plant was obtained at 20 and $25 \mathrm{~cm}$ plant spacings. The leaf/canopy temperature, leaf area, and chlorophyll content in the leaves, which were among the physiological parameters examined in the study, were not affected by the plant spacing applications, but plant density affected the NDVI. As a result of this study, it was concluded that the cultivation of the BA 119 cotton variety at a $5 \mathrm{~cm}$ plant density or without thinning performs better than at a sparse plant density $(20$ or $25 \mathrm{~cm})$ and should be preferred. Yield estimation could be made in the flowering period using the NDVI at different plant densities in cotton.

Acknowledgements. This research was supported by the Scientific Research Projects Coordination Unit of Siirt University as a graduate study with the project number "2018-SIÜFEB-024". We thank the BAP unit for their contributions. We would also like to thank Mr. Arda KARADEMIR, the civil engineer who determined the leaf areas using the AutoCAD program, and Ms. Seyhan YAŞAR, the textile engineer responsible for the GAPUTAEM fibre analysis laboratory, who conducted fibre analysis. 


\section{Rojda ALTUNDAG, Emine KARADEMIR}

\section{REFERENCES}

Afzal, M.N., Tariq, M., Ahmad, M., Mubeen, K., Khan, M.A., Afzal, M.U. \& Ahmad, S. (2018). Dry matter, lint mass and fiber properties of cotton in response to nitrogen application and planting Didensities. Pak. J. Agric. Res., 32(2): 229-240, DOI: 10.17582/ journal.pjar/2019/32.2.229.240.

Akbar, H.M., Akram, M., Hassan, M.W., Hussain, A., Rafay, M. \& Ahmad, I. (2015). Growth, yield and water use efficiency of cotton (Gossypium hirsutum L.) sown under different planting techniques. Custos e @gronegócio on line 11 (1): 142160.www.custoseagronegocioonline. com.br\%2F.

Akçar, H. \& Gencer, O. (1987). Pamuk Bitkisel Yapısı, Yetiştirilmesi Islahı ve Lif Teknolojisi. ISBN: 978-605-464922-8-222, Ankara, s. 485.

Ali, A., Tahir, M., Ayub, M., Ali, I., Wasaya, A. \& Khalid, F. (2009). Studies on the effect of plant spacing on the yield of recently approved varieties of cotton. Pak. J. Life Soc. Sci. 7 (1):25-30, Corpus ID: 13026 5235.

Awan, H., Awan, M., Mansoor, M., Khan, E.A. \& Khan, M.A. (2011). Effect of sowing time and plant spacing on fiber quality and seed cotton yield. Sarhad J. Agric., 27(3): 411-413.

Azizpour, K., Shakiba, M.R., Moghadan, M., Elah, N.N. \& Elah, E.E. (2005). Effects of plant density on morphological characteristics and yield of two cotton cultivars at Varamin Region. J.Agric.Sci., 15(1): 137-151, https://www.sid.ir/en/journal NiewPaper.aspx?ID=68713.

Baker, S.H. (1976). Response of cotton to row patterns and plant populations. Agron. J., 68: 85-88, DOI: 10.2134/ agronj1976.00021962006800010023 $x$.

Bednarz, C.W., Bridges, D.C. \& Brown, S.M., (2000). Analysis of cotton yield stability across population densities.
Agron. J., 92(1):128-135, DOI: 10.21 34/agronj2000.921128x.

Bednarz, C.W., Shurley, W.D., Anthony, W.S. \& Nichols, R.L. (2005). Yield, quality, and profitability of cotton produced at varying plant densities. Agron. J., 97: 235-240.

Bridge, R.R., Meredith, W.R. \& Chism, J.F. (1972). Influence of planting method and plant population on cotton (Gossypium hirsutum L.). Agron. J., 65(1): 104-109.

Chen, Z., Niu, Y., Zhao, R., Han, C. \& Huanyong, L. (2019). The combination of limited irrigation and high plant density optimizes canopy structure and improves the water use efficiency of cotton. Agric. Water Manag., 218(C): 139-148, DOI: 10.1016/j.agwat.2019.03.037.

Darawsheh, M.K., Khah, E.M., Aivalakis, G. \& Chachalis, D., Sallaku, F. (2009a). Cotton row spacing and plant density cropping systems I. Effects on accumulation and partitioning of dry mass and LAI. J. Food. Agric. Environ., 7 (3\&4): 258-261.

Darawsheh, M.K., Chachalis, D., Aivalakis, G. \& Khah, E.M. (2009b). Cotton row spacing and plant density cropping systems II. Effects on seed cotton yield, boll components and lint quality. J. Food, Agric. Environ., 7(3\&4): 262-265.

Darawsheh, M.K., Kakaboukı, I., Roussıs, I. \& Bılalıs, D.J. (2019). Cotton response to planting patterns under effect of typical and limited irrigation regime. Notulae Bot. Horti Agrobot. Cluj-Napoca, 47(4):12061214, DOI:10.15835/nbha47411712

Delaney, D.P., Monks, C.D., Reeves, D.W., Bannon, J.S. \& Durbin, R.M.(1999). Planting dates and populations for UNR cotton in Central Alabama. Proceedings of the Beltwide Cotton Conference, 2: 12781279.

Dong, H., Weijiang, L., Wei, T., Zhenhuai, L., Dongmei, Z. \& Yuehua, N. (2005). Yield, quality and 


\section{PLANT SPACING \& ITS EFFECT ON YIELD, FIBRE QUALITY \& PHYSIOLOGICAL PARAMETERS IN COTTON}

leaf senescence of cotton grown at varying planting dates and plant densities in the Yellow River Valley of China. Field Crops Res., 2(3): 106115, DOI:10.1016/j.fcr.2005.12.008.

Düven, E. (1992). Çukurova koşullarında farklı gelişme özelliklerine sahip üç pamuk çeşidinde (G. hirsutum L.) sırt ve düz toprak işleme şekilleri ile farklı sıra üzeri uzaklıkların verim ve verim unsurlarına etkisi üzerine bir araştırma. Çukurova Üniversitesi Fen Bilimleri Enstitüsü, Yüksek Lisans Tezi, Adana. $55 \mathrm{~s}$.

Fang, L., Mathis, G., Ritchie, G. \& Han, Y. (2014). Optimizing irrigation and plant density for improved cotton Yield and fiber quality. Agron. J., 106(4):1111-1118, DOI: 10.2134/agr onj13.0503.

Gwathmey, C.O., Tyler, D.D. \& Yin, X. (2010). Prospects fo monitoring cotton crop maturity With NDVI. Agron. J., 102(5): 1352-1360, DOI: 10.2134/agronj2010.0148.

Gwathmey, C.O., Leib, B.G. \& Main, L.C. (2011). Lint yield and crop maturity responses to irrigation in a shortseason environment. J. Cotton Sci., 15: 1-10, https://www.cotton.org/ journal/2011-15/1/upload/JCS151.pdf

Hall, A.E. \& Ziska, L.H. (2000). Crop breeding strategies for 21st century. Climate Change and Global Crop Productivity (eds. K. R. Reddy and H. F. Hodges), 407-423.

Hawkins, B.S. \& Peacock, H.A. (1971). Response of 'atlas' cotton to variations in plants per hill and withinrow spacings. Agron. J., 63: 611-613, DOI:10.2134/agronj1971.000219620 06300040029x.

Heitholt, J.J. (1995). Cotton flowering and boll retention in different planting configurations and leaf shapes. Agron. J., 87: 994-998, DOI: 10.2134/agronj1995.0002196200870 $0050037 x$.

Heitholt, J.J. \& Sassenrath-Cole, G.F. (2010). Inter-plant competition: Growth responses to plant density and row spacing. Physiol. Cotton,
179-186, DOI:10.1007/978-90-4813195-2_17.

Incekara, F. ve Turan, Z.M. (1977). Ekim sıklığının dört pamuk çeşidinde bazı agronomik karakterlere ve değişik yöntemlere göre analiz edilen erkencilik üzerine etkisi. E.Ü.Z.F. yayınları, No. 303, Bornova-İzmir, 69 s.

lqbal, M., Ahmad, S., Nazeer, W., Muhammad, T., Khan, M.B., Hussain, M., Mehmood, A., Tauseef, M., Hameed, A. \& Karim, A. (2012). High plant density by narrow plant spacing ensures cotton productivity in elite cotton (Gossypium hirsutum L.) genotypes under severe cotton leaf curl virus (CLCV) infestation. Afr. J. Biotechnol., 11(12): 2869-2878, DOI: 10.5897/AJB11.3259.

Janat, M. \& Khalout, A.R. (2011). Evaluation of drip-irrigated cotton grown under different plant population densities and two irrigation regimes. Commun. Soil Sci. Plant Anal., 42: 741-752, DOI: 10.1080/00103624.2011.55037.

Johnson, J.R. \& Saunders, J.R, (2003). Evaluation of chlorophyll meter for nitrogen management in cotton. Annual Report, pp.162-163.

Jost, P., Cothren, T. \& Gerik, T.J. (1998). Growth and yield of ultra-narrow row and conventionally-spaced cotton. Reprinted from the Proceedings of the Beltwide Cotton Conference, 2: 1383-1383.

Kaplan, M., Fidan, M.S., Kökten, K. \& Ülger, I. (2017). Chemical composition and in vitro gas production of whole cottonseed (Gossypium hirsitum L.) cultivars. Journal of Faculty of Veterinary Medicine, Erciyes University, 14(2): 93-99.

Kaynak, M.A., Oğlakcı, M. ve Çölkesen, M. (1994). Harran Ovası Koşullarında, Pamukta (Gossypium hirsutum L.), Farklı Sıra Arası ve Sıra Üzeri Uzaklıklarının Verim, Verim Unsurları ve Lif Özelliklerine Etkisi Üzerinde Bir Araştırma. Tarla Bitkileri 
Kongresi, 25-29 Nisan, Cilt: I, s. 214217, Bornova, 1994.

Kaynak, M.A. (1995). Harran Ovası Koşullarında Farklı Sıra Arası Uzaklıklarının, Erkenci Pamuk Çeşitlerinin Verim ve Verim Unsurlarına Etkisi Üzerine Bir Araştırma. Harran Üniversitesi Ziraat Fakültesi Dergisi. 1(1): 1-19.

Kerby, T.A., Cassman, K.G. \& Keeley, M. (1990). Genotypes and plant densities for narrow-row cotton systems. I. Height, nodes, earliness, and location of yield. Crop Sci., 30: 44-649, DOI: 10.2135/cropsci1990. 0011183X003000030034x.

Khan, N., Xing, F., Feng, L., Wang, Z., Xin, M., Xiong, S., Wang, G., Chen, H., Du, W. \& Li, Y. (2020). Comparative yield, fiber quality and dry matter production of cotton planted at various densities under equidistant row arrangement. Agron., 10(2): 232, DOI:10.3390/agronomy10 020232.

Kumar, A., Karunakar, A.P., Nath, A. \& Meena, B.R. (2017). The morphological and phenological performance of different cotton genotypes under different plant density. J. Appl. Nat. Sci., 9(4): 2242 -2248, DOI: 10.31018/JANS.V9I4. 1518.

Liu, L., Li, C., Han, Y., Wang, Z., Feng, L., Zhi, X., Yang, B., Lei, Y., Du, W. \& Li, Y. (2019). Adjusting cotton planting density under the climatic conditions of Henan Province, China. PLoS One, 14(9): 1-12, DOI: 10.1371/journal.pone.0222395.

Mahil, E.I.T. \& Lokanadhan, S. (2017). Yield and yield components of winter cotton (Gossypium hirsutum L.) genotypes influenced by plant spacings. Int. J. Plant Soil Sci., 20(6): 1-6, DOI: 10.9734/IJPSS/2017/38591

Mert, M., Aslan, E., Akıscan, Y., Calıskan, M. E., (2005). Response of cotton (Gossypium hirsutum L.) to different tillage systems and intra-row spacing. Soil Tillage Res., DOI: 10.1016/j.still.2005.01.016.
McCarty, J., Jenkins, J., Hayes, R. \& Wubben, M. (2017). Effects of plant density on boll retention and yield of cotton in the mid-south. Am. J. Plant Sci., 8: 891-906, DOI: 10.4236/ajps. 2017.84060

Özdemir, M. (2007). The effect of plant density on yield and lint technological traits on cotton production after wheat. Sütçü Imam University, Natural and Applied Sciences, MSc thesis, Kahramanmaraş, $50 \mathrm{p}$.

Pask, A.J.D., Pietragalla, J., Mullan, D.M. \& Reynolds, M.P. (Eds.) (2012). Physiological breeding II: A field guide to wheat phenotyping. Mexico, D.F, CIMMYT. https://repository.cim myt.org/xmlui/bitstream/handle/10883 11288/96144.pdf (Erişim Tarihi: 9 Ocak 2017).

Ramirez, M.B., Allen, P.B., Freeland, R.S. \& Wilkerson, J.B. (2017). Cotton canopy NDVI: reducing the ground exposure effect. Trans ASABE, 60(2): 293-301.

Samani, M.R.K., Khajehpour, M.R. \& Ghavaland, A. (1999). Effects of row spacing and plant density on growth and dry matter accumulation in cotton in Isfahan. Iranian J. Agric. Sci., 29(4): 667-679.

Sawan, Z.M., (2016). Plant density; plant growth retardants: Its direct and residual effects on cotton yield and fiber properties. Cogent Biol., 2:1234959: 1-12, DOI: 10.1080/ 23312025.2016.1234959

Silva, P.T., Macedo, F.G., Camacho, M.A., Santos, C., Santi, A., Krause, W., Rambo, J.R., (2012). Spacing and plant density effect on reproductive development of herbaceous cotton. Scientia Plena, 8(5): 1-8.

Stephenson, D.O., Barber, L.T. \& Bourland, F.M. (2011). Effect of twin-row planting pattern and plant density on cotton growth, yield, and fiber quality. J. Cotton Sci., 15: 243250.

Tümer, H.T. (2010). The effects of ginning methods on the cotton quality. MSc 


\section{PLANT SPACING \& ITS EFFECT ON YIELD, FIBRE QUALITY \& PHYSIOLOGICAL PARAMETERS IN COTTON}

thesis, Çukurova University Institute of Natural and Applied Sciences, Adana, 51p.

Ünay, A. \& İnan, Ö. (1994). The investigation on plant density in cotton (G. hirsutum L.). Türkish J. Agric. For., 20: 197-200.

Yao, H., Zhang, Y., Yi, X., Zhang, X. \& Zhang, W. (2016). Cotton responds to different plant population densities by adjusting specific leaf area to optimize canopy photosynthetic use efficiency of light and nitrogen. Field Crops Res., 188: 10-16, DOI: 10.1016/j.fcr.2016.01.012.

Ye, S., Jiang, C., Liu, F., Tian, C., Li, C., Han, W. \& Wu, D. (2021). Optimal planting density for achieving higher yield and fiber quality of two types of cotton (Gossypium hirsutum L.). Appl. Ecol. Environ. Res., 19(3): 2495-2505, DOI: 10.15666/aeer/ 1903_24952505.

Wang, X., Hou, Y., Mingwei, D., Xu, D., Lu, H., Tian, X. \& Li, Z. (2016). Effect of planting date and plant density on cotton traits as relating to mechanical harvesting in the Yellow River valley region of China. Field Crops Res., 198: 112-121, DOI: 10.1016/j.fcr.2016.09.010.
Xie, T., Su, P., An, L., Shan, L., Zhou, Z. \& Chai, Z. (2016). Physiological characteristics of high yield under cluster planting: photosynthesis and canopy microclimate of cotton. Plant Prod. Sci., 19(1): 165-172, DOI: 10.1080/1343943X.2015.1128088.

Zhang, W.F., Wang, Z.L., Yu, S.L., Li, S.K., Fang, J. \& Tong, W.S. (2004). Effects of planting density on canopy photosynthesis, canopy structure and yield formation of high-yielded cotton in Xinjiang, China. Acta Phytoecologica Sinica, 28: 164-171, DOI: 10.17521/cjpe.2004.0024.

Zhao, W., Yan, Q., Yang, H., Yang, X., Wang, L., Chen, B., Meng, Y. \& Zhou, Z. (2019). Effects of mepiquat chloride on yield and main properties of cottonseed under different plant densities. J. Cotton Res., DOI: 10.1186/s42397-019-0 026-1

Zhi, X.Y., Han, Y.C., Li, Y.B., Wang, G.P., Du, W.L., Li, X.X., Mao, S.C. \& Lu, F. (2016). Effects of plant density on cotton yield components and quality. J. Integr. Agric., 15(7): 1469-1479, DOI: 10.1016/S2095-3119(15)611741

(C) 2021 by the authors; licensee Journal of Applied Life Sciences and Environment, Iasi, Romania. This article is an open access article distributed under the terms and conditions of the Creative Commons Attribution License (http://creativecommons.org/licenses/by/4.0/). 